\title{
THYROTROPHIG HORMONE CONTENT OF THE PITUITARY OF MOLTING AND LAYING HENS
}

\author{
YUICHI TANABE, TSUNEO ABE, KENTARO HIMENO, \\ TADATSUNE KANEKO, KAZUSHIGE MOGI, \\ YUICHI SAEKI AND TATSUO HOSODA \\ National Institute of Agricultural Sciences, Livestock Section, Chiba
}

In recent papers, Tanabe et al. $(1956,1957)$ reported that no increase in the uptake of $\mathrm{I}^{131}$ by the thyroid was observed in molting hens as compared with laying hens, and no acceleration in the release of $\mathrm{I}^{131}$ as thyroid hormone from the thyroid of the hen was observed either in molting period or in pre-molting period. Further-more, it has been shown that thiouracil feeding does not prevent naturally occurring molt of the hen (Sulman and Perek, 1947; Himeno and Tanabe, 1957a). These results indicate that natural molting in the hen is not induced by the increased activity of the thyroid.

The present investigations were initiated to determine the thyrotrophic hormone content of the pituitary of molting and laying hens.

\section{MATERIALS AND METHODS}

Anterior pituitaries were obtained from laying hens and non-laying hens in annual molt of Single Comb White Leghorns, weighing $1.5-2.0 \mathrm{~kg}$. Their age ranged from 1 to 2 years. The experimental period was September to December. The anterior pituitaries dissected from the heads on slaughtering were acetone-dried and pulverized. One-day-old Single Comb White Leghorn cockerels weighing $30-40 \mathrm{~g}$ were used as assay animals. They were kept in an electric brooder, and maintained only on water. Carrier free $\mathrm{P}^{32}\left(\mathrm{Na}_{2} \mathrm{HPO}_{4}\right)$ was furnished from the Radiochemical Center, Amersham, England.

Thyrotrophic hormone content of the pituitary was determined by the two methods, microhistometric method based on the increase in the epithelial cell height of the thyroids of the recipient chicks, and biochemical method based on the increase in $\mathrm{P}^{32}$ uptake by the thyroids of the recipient chicks.

The microhistometric method by Rawson and Salter (1940) was modified by us and was used in the present assay. Acetone-dried pituitary powder was suspended in a volume of $0.4 \mathrm{cc}$ distilled water, and taken into a $1 \mathrm{cc}$ tuberculin syringe. Each volume contained 2 pituitaries. Daily injection of $0.1 \mathrm{cc}$ suspension was given intramuscularly for 4 days. The control chicks were injected with $0.4 \mathrm{cc}$ isotonic saline. The chicks were sacrificed $24 \mathrm{hrs}$. after the last injection. The thyroid glands were removed, fixed in $10 \%$ formalin, and enbedded in paraffin. Sections cut serially at $5 \mu$ were stained with hematoxilin and eosin. Epithelial cell height was measured on 30 follicles on a section passed through the middle portion of each left and right thyroid.

Biochemical method was the same as the methods by Lamberg (1953) and by Wahlberg

Received for publication March 21, 1958. 
(1955). Acetone-dried pituitary powder was suspended to $0.2 \mathrm{cc}$ distilled water. Each volume contained 1 pituitary. One-day-old cockerels were injected with the $0.2 \mathrm{cc}$ suspension subcutaneously, and sacrificed $8 \mathrm{hrs}$. after the injection. One hour before the sacrifice the animals were given an intraperitoneal injection of $10 \mu \mathrm{c}$ of $\mathrm{P}^{32}$. Control chicks received $0.2 \mathrm{cc}$ of isotonic saline $8 \mathrm{hrs}$. before the sacrifice and $10 \mu \mathrm{c} \mathrm{P}^{3} \quad \mathrm{l} \mathrm{hr}$. before the sacrifice. The thyroid glands were removed and dried at $95^{\circ} \mathrm{C}$ in a thermostat over night. The radioactivity of $\mathrm{P}^{32}$ of the thyroid gland was measured with a Geiger-Müller counter.

\section{RESULTS}

The epithelial cell height of the thyroids of the chicks receiving 4 injections of the suspension of the pituitaries of molting and laying hens and isotonic saline is shown in Table 1. The epithelial cell height of the thyroids of the chicks injected with the pituitaries of molting and laying hens, at the two pituitary dosage level per chick, significantly increased compared with that of the thyroids of the chicks injected with isotonic saline. The epithelial cell height of the thyroids of the chicks injected with the pituitaries of laying hens is somewhat higher than that of the thyroids of the chicks injected with the pituitaries of molting hens, although the difference between the two is not significant.

Table 1. Thyrotrophin content of the pituitary of molting and laying hens measured by the epithelial cell height of the thyroid of the recipient cockerels

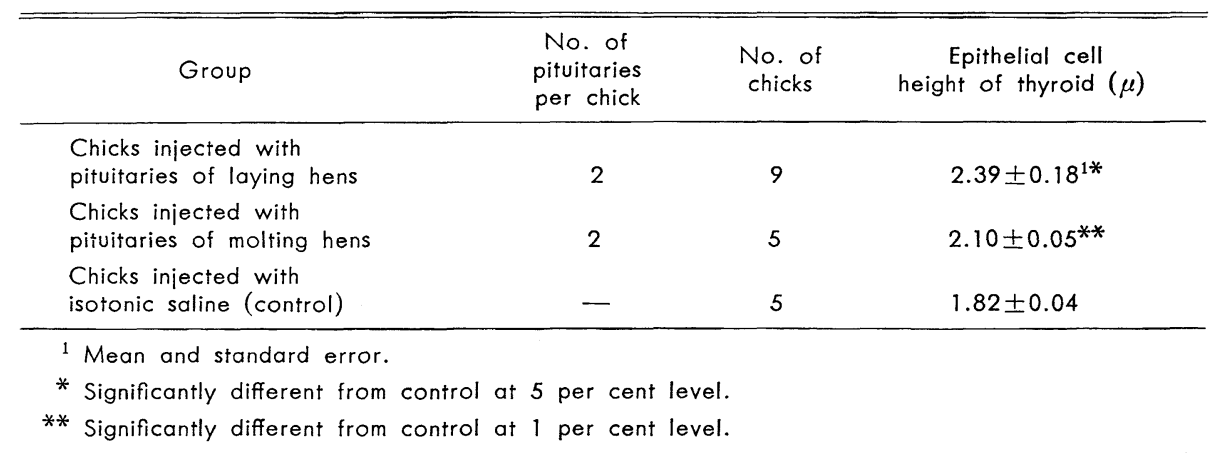

The $\mathrm{P}^{32}$ uptake by the thyroids of the chicks receiving one injection of the suspension of the pituitaries of molting and laying hens and $10 \mu \mathrm{c}$ of $\mathrm{P}^{32}$ is shown in Table 2. $\mathrm{P}^{32}$ uptake by the thyroids of the chicks injected with the pituitaries of molting and laying hens, at the one pituitary dosage level per chick, significantly increased compared with that of the thyroids of the chicks injected with isotonic saline. The $\mathrm{P}^{32}$ uptake by the thyroids of the chicks injected with the pituitaries of molting hens is higher than that of the thyroids of the chicks injected with the pituitaries of laying hens, although the difference between the two is insigificant. 
Table 2. Thyrotrophin content of the pituitary of molting and laying hens measured by $\mathrm{P}^{32}$-uptake at the thyroid of the recipient one-day-old cockerels

\begin{tabular}{lcccc}
\hline \multicolumn{1}{c}{ Group } & $\begin{array}{c}\text { No. of } \\
\text { pituitaries } \\
\text { per chick }\end{array}$ & $\begin{array}{c}\text { No. of } \\
\text { chicks }\end{array}$ & $\begin{array}{c}\text { c. p. m. per } \\
\text { thyroid }\end{array}$ & $\begin{array}{c}\text { c. p. m. ratio } \\
\text { treated: control }\end{array}$ \\
\hline $\begin{array}{l}\text { Chicks injected with } \\
\text { pituitaries of laying hens }\end{array}$ & 1 & 6 & $875 \pm 177^{1 *}$ & $3.26 \pm 0.68^{1}$ \\
$\begin{array}{l}\text { Chicks injected with } \\
\text { pituitaries of molting hens } \\
\begin{array}{l}\text { Chicks injected with } \\
\text { isotonic saline (control) }\end{array}\end{array}$ & 1 & 5 & $562 \pm 111^{*}$ & $2.14 \pm 0.41$ \\
\hline
\end{tabular}

1 Mean and standard error.

* Significantly different from control at 5 per cent level. c. p. m.: counts per minute.

\section{DISGUSSION}

The present studies demonstrate that thyrotrophic hormone content of the pituitary of molting hens is rather lower than that of the pituitary of laying hens. The previous studies showed that any increase in thyroidal activity was not observed either in molting or in pre-molting period in the hen, and molt occurred whenever laying ceased and ovarian activity decreased (Tanabe et al., 1957); moreover, the administration of Enheptin (2-amino, 5-nitrothiazole) soon suppressed egg laying in any season of the year; however, molt occurred only in the hen which completed the preceding molt six months or more before (Himeno and Tanabe, 1957b), and daily injection of $1.25 \mathrm{mg}$ of stilbestrol to the hen completely inhibited the naturally occurring molt in the fall (Tanabe and Himeno, 1958). These results indicate that natural molting in the hen is induced by the decrease in the secretion of estrogen from the ovary, caused by the decrease in the ovarian activity, together with the senile deterioration of the structure in the feather follicle maintaining the old feathers after about six months from the preceding molt, but not induced by the increased activity of the thyroid.

We previously showed that the gonadotrophic hormone content of the pituitaries of non-laying hens in molt was significantly higher than that of the pituitaries of laying hens (Saeki et al., 1956). It seems that the increase in gonadotrophic potency in the pituitary of non-laying hens in molt is primarily caused by the disproportional increase in FSH as compared with that in LH. The decrease in ovarian activity, which induces the cease of laying in the hen in fall and subsequent molt, may be induced by the inability of utilization of gonadotrophin by the ovary caused by the unbalance between FSH and LH, which may result from shortening daylight length.

\section{SUMMARY}

Thyrotrophic hormone content of the pituitary of molting and laying hens was determined by the microhistometric method based on the increase in epithelial cell height of the thyroids of the recipient chicks, and the biochemical method 
based on the increase in $\mathrm{P}^{32}$ uptake by the thyroids of the recipient chicks. By either measurement thyrotrophic hormone content of the pituitary of laying hens was higher than that of the pituitary of molting hens, although no significant difference was observed between the two. Any evidence of the activation of pituitary-thyroid system was not observed in molting period of the hen.

\section{REFERENCES}

Himeno, K. and Y. Tanabe (1957a). Poultry Sci. 36, 835.

Himeno, K. and Y. Tanabe (1957b). Endocrinol. Japon. 4, 268.

Lamberg, B.-A. (1953). Acta Med. Scandinav. Suppl. 279.

Rawson, R. W. and W. T. Salter (1940). Endocrinology 27, 155.

Saeki, Y., K. Himeno, Y. Tanabe and T. Katsuragi (1956). Endocrinol. Japon. 3, 87.

Sulman, F. and M. Perek (1947). Endocrinology 41, 514.

Tanabe, Y., H. Nozaki and K. Makino (1956). Radioisotopes 5, 52.

Tanabe, Y., K. Himeno and H. Nazaki (1957). Endocrinology 61, 661.

Tanabe, Y. and K. Himeno (1958). Unpublished.

Wahlberg, P. (1955). Acta Endocrinol. Suppl. 23. 